\title{
Deteksi Perubahan Luasan Mangrove Teluk Youtefa Kota Jayapura Menggunakan Citra Landsat Multitemporal
}

\section{Baigo Hamuna ${ }^{1}$ dan Rosye H.R. Tanjung ${ }^{2}$}

1FMIPA, Universitas Cenderawasih, Kota Jayapura, Papua, Indonesia

2FMIPA, Universitas Cenderawasih, Kota Jayapura, Papua, Indonesia

Email Koresponden: bhamuna@yahoo.com

Diterima: 8 Maret 2018 /Refisi: 03 September 2018 Disetujui: 19 September 2018

(c) 2018 Fakultas Geografi UGM dan Ikatan Geograf Indonesia (IGI)

\begin{abstract}
Abstrak Kondisi mangrove di kawasan Teluk Youtefa, baik dari aspek kualitas maupun kuantitasnya terus mengalami penurunan dari tahun ke tahun. Penelitian ini dilakukan untuk mengetahui seberapa besar perubahan luasan mangrove yang terjadi di kawasan Teluk Youtefa, Kota Jayapura dari tahun 1994 sampai tahun 2017 dengan menggunakan citra satelit Landsat 5 TM dan Landsat 8 OLI. Pengamatan kondisi mangrove di lapangan dilakukan dengan menggunakan GPS dan pengolahan citra menggunakan algoritma NDVI dengan klasifikasi supervised. Tumpang susun peta hasil interpretasi citra satelit untuk mengetahui sebaran dan perubahan luasan kawasan mangrove. Hasil penelitian menunjukan bahwa luasan mangrove pada tahun 1994 sebesar 392,45 ha dan luasan mangrove pada tahun 2017 mengalami penurunan menjadi 233,12 ha. Perubahan luasan mangrove dalam kurun waktu 23 tahun sebesar 159,34 ha atau sebesar 40,59\%. Perubahan kawasan mangrove pada umumnya disebabkan oleh faktor antropogenik seperti penebangan, perubahan fungsi kawasan mangrove menjadi jalan, jembatan, pemukiman dan perubahan secara alami.
\end{abstract}

Kata kunci : landsat, mangrove, perubahan luasan, teluk youtefa

\begin{abstract}
The condition of mangrove in Youtefa Bay, both qualitatively and quantitatively has decreased from year to year. This research was conducted to determine how much of the change occurring mangrove area in Youtefa Bay, Jayapura City from 1994 to 2017 by using Landsat 5 TM images and Landsat 8 OLI. Monitoring of mangrove condition in the field used GPS, and processing of images used NDVI algorithm with supervised classification. Map overlaying satellite imagery interpretation to determine the distribution and changes of mangrove area. The result of research showed that mangrove area in 1994 was about 392.45 hectares, mangrove area in 2017 have decreased becoming was 233.12 hectares. Changing of mangrove area for 23 years was about 159.34 hectares or $40.59 \%$. Changes in mangrove were generally caused by anthropogenic factors such as logging, changes over the function of mangroves into the road, bridge, settlement and change naturally.
\end{abstract}

Keywords : extended area, landsat, mangrove, youtefa bay

\section{PENDAHULUAN}

Salah satu bagian terpenting dari rantai ekologi di wilayah pesisir adalah ekosistem mangrove. Mangrove memiliki fungsi ganda dan merupakan mata rantai yang sangat penting dalam memelihara keseimbangan siklus biologi di suatu perairan. Fungsi fisik kawasan mangrove yaitu menjaga keseimbangan ekosistem perairan pantai, melindungi pantai dan tebing sungai terhadap pengikisan atau erosi pantai, menahan dan mengendapkan lumpur serta menyaring bahan tercemar. Fungsi lainnya adalah sebagai penghasil bahan organik yang merupakan sumber makanan biota, tempat berlindung dan memijah berbagai jenis udang, ikan, dan berbagai biota lainnya (Bengen, 2000; Valiela et al., 2001; Bosire et al., 2005).

Mangrove di wilayah pesisir Kota Jayapura terletak di kawasan pesisir Teluk Youtefa. Teluk Youtefa terkenal dengan potensi pemandangan alam pesisir dan laut yang indah, sehingga pada tahun 1996 ditetapkan sebagai Taman Wisata Alam sesuai surat keputusan Menteri Kehutanan Nomor: 714/Kpts/-2/1996. Mangrove sangat berperan penting bagi kehidupan masyarakat kawasan Teluk Youtefa. Selain itu, kawasan mangrove ini sangat penting artinya bagi kaum perempuan Papua karena merupakan lumbung makanan dan tempat berinteraksi sosial dan budaya bagi kaum perempuan pada saat mencari kerang rawa, siput, udang dan kayu bakar. Oleh karena itu, kawasan mangrove di Teluk Youtefa sering disebut sebagai "hutan perempuan". Banyaknya manfaat yang dapat diperoleh masyarakat dari mangrove tersebut terkadang menyebabkan eksploitasi yang berlebihan yang berakibat rusaknya kawasan mangrove yang berdampak pada menurunnya fungsi dari mangrove.

Mangrove tengah mengalami penurunan kualitas dan kuantitas pada tingkat yang mengkhawatirkan di seluruh dunia. Secara global dan selama lebih dari dua dekade (1980-2005) dunia telah kehilangan mangrove lebih dari 25\% dari total luasan (Giri et al., 2011). Demikian halnya dengan kondisi mangrove di kawasan Teluk Youtefa. Kondisi mangrove di kawasan Teluk Youtefa saat ini sudah sangat memprihatinkan. Luas areal mangrove di kawasan Teluk Youtefa semakin berkurang seiring dengan tingginya tingkat 
pemanfaatan lahan untuk kebutuhan pembangunan pemukiman dan infrastruktur jalan dan jembatan di Kota Jayapura (Handono dkk, 2014; Paulangan, 2014; Antoh, 2015). Selain itu, apabila ditinjau dari aspek kerentanan wilayah pesisir, maka kawasan mangrove di pesisir Teluk Youtefa merupakan kawasan yang sangat rentan (Hamuna et al., 2018). Perubahan luasan tersebut masih berlangsung sampai saat ini mengingat tingginya aktifitas pembangunan di wilayah pesisir Kota Jayapura. Disamping itu, adanya ketergantungan masyarakat lokal yang tinggi terhadap ekosistem mangrove sebagai tempat mencari nafkah untuk peningkatan ekonomi sehingga tekanan terhadap ekosistem mangrove semakin meningkat pula.

Melihat kondisi mangrove di Teluk Youtefa saat ini, perlu dilakukan suatu kajian mengenai kondisi terkini dan perubahan mangrove di kawasan Teluk Youtefa. Salah satu metode yang dapat digunakan adalah dengan memanfaatkan teknologi penginderaan jauh. Mangrove dapat diidentifikasi dengan menggunakan teknologi penginderaan jauh, dimana letak geografis mangrove yang berada pada daerah peralihan darat dan laut memberikan efek perekaman yang khas jika dibandingkan obyek vegetasi darat lainnya (Faizal dan Amran, 2005). Selain itu, nilai spektral pada citra satelit dapat diekstraksi menjadi informasi obyek jenis mangrove pada kisaran spektrum tampak dan inframerah dekat (Suwargana, 2010). Beberapa penelitian yang telah dilakukan dengan memanfaatkan teknologi penginderaan jauh untuk mendeteksi sebaran spasial ataupun perubahan luasan mangrove di Indonesia antara lain Wulandari dan Samsu (2013) mengidentifikasi sebaran dan tingkat kesuburan mangrove di pentai pesisir timur Surabaya, Hidayah dan Wiyanto (2013) menganalisa perubahan luas mangrove di Kabupaten Sidoarjo, Jhonnerie dkk (2014) mendeteksi perubahan tutupan mangrove di Sungai Kembung Bengkalis, Imburi dkk (2015) memetakan hutan mangrove di wilayah estuari Sungai Andai Manokwari, Rumada dkk (2015) mengindentifikasi kerusakan mangrove di Taman Hutan Raya Ngurah Rai Bali, serta Faturrohmah dan Marjuki (2017) mengidentifikasi dinamika spasial mangrove di wilayah pesisir Kabupaten Demak.

Melihat kondisi mangrove di kawasan Teluk Youtefa saat ini dan terbatasnya informasi spasial perubahan luasan mangrove Teluk Youtefa, maka penelitian ini dilakukan bertujuan untuk mendeteksi perubahan luasan dan kerapatan mangrove di Teluk Youtefa, Kota Jayapura yang terjadi dalam rentang waktu 1994 dan 2017 dengan menggunakan teknologi penginderaan jauh citra satelit Landsat multitemporal. Informasi kondisi dan pemetaan degradasi mangrove tersebut dapat digunakan untuk berbagai pemanfaatan dan pertimbangan dalam pengelolaan hutan mangrove di kawasan Teluk Youtefa.

\section{METODE PENELITIAN}

Penelitian ini berlokasi di kawasan Taman Wisata Alam Teluk Youtefa, Kota Jayapura, Provinsi Papua. Data yang digunakan terdiri atas data primer dan data sekunder. Data primer antara lain citra satelit landsat dan data lapangan. Citra satelit Landsat 5 TM tanggal akuisisi 2 Agustus 1994 dan Landsat 8 OLI tanggal akuisisi 21 Januari 2017, path 101 dan row 062. Data lapangan berupa data jenis mangrove dan data koordinat posisi mangrove dan tutupan lahan lainnya di lapangan menggunakan GPS (Global Positioning System) yang digunakan untuk proses validasi atau pengujian keakuratan klasifikasi. Sedangkan data sekunder berupa data dari instansi terkait dan hasilhasil penelitian yang relevan dengan topik penelitian.

Untuk mengidentifikasi vegetasi mangrove dengan data citra satelit Landsat 5 TM atau Landsat 7 ETM+ mengacu pada eskplorasi citra komposit RGB 453. Sedangkan pada citra satelit Landsat 8 digunakan komposit RGB 564, dimana ketiga band tersebut termasuk dalam kisaran spektrum tampak dan inframerah-dekat dan mempunyai panjang gelombang yang sesuai dengan panjang gelombang band 4, band 5 dan band 3 pada citra satelit Landsat 7 ETM+ (Purwanto dkk, 2014). Pada tahap awal melakukan klasifikasi citra dengan metode supervised, terlebih dahulu membuat training area untuk mengelompokan piksel-piksel yang berwarna sama. Training area ini akan mewakili nilai spektral yang menjadi acuan bagi piksel lainnya, dimana yang memiliki nilai spektral yang mirip dengan nilai spektral training area akan diklasifikasikan menjadi kelas penutupan lahan yang sama. Klasifikasi supervised dilakukan dengan menggunakan metode Maximum Likelihood Classification (MLC). Untuk mengetahui tingkat akurasi dari hasil klasifikasi digunakan metode uji ketelitian klasifikasi confusion matrix. Selanjutnya nilai indeks vegetasi yang digunakan dalam penelitian ini adalah hasil dari pengolahan citra menggunakan transformasi Normalized Difference Vegetation Index (NDVI). Nilai indeks vegetasi tersebut dihitung sebagai rasio antara pantulan yang terukur dari band merah (RED) dan band infra-merah (NIR) (Green et al., 2000) dengan persamaan sebagai berikut:

$$
N D V I=(N I R-R E D) /(N I R+R E D)
$$

Hasil dari analisis NDVI digunakan untuk menentukan nilai kerapatan mangrove. Kemudian nilai kelas NDVI tersebut diklasifikasi ulang menjadi tiga kelas, yaitu kerapatan jarang, kerapatan sedang dan kerapatan padat sebagaimana disajikan pada Tabel 1. Semua proses tahapan pengolahan data citra Landsat tersebut menggunakan software Er mapper 7.0. Perubahan tutupan lahan mangrove pada penelitian ini mencakup aspek spasial maupun temporal, yaitu perubahan persebaran tutupan lahan mangrove dalam kurun waktuantaratahun 1994hingga2017. Berdasarkan 
hasil interpretasi distribusi tutupan lahan mangrove pada tahap sebelumnya, selanjutnya dilakukan teknik overlay menggunakan software ArcMap 10.5. Pada tahap ini, hasil analisis akan menghasilkan deskripsi di mana saja tutupan lahan mangrove mengalami penambahan maupun mengalami pengurangan, serta besar perubahan luasan dan kerapatan mangrove.

Tabel 1. Kriteria nilai NDVI

\begin{tabular}{lrr}
\hline Tingkat Kerapatan & $\begin{array}{r}\text { Kerapatan } \\
(\text { pohon/Ha) }\end{array}$ & NDVI \\
\hline Mangrove Jarang & $<1000$ & $0,10-0,20$ \\
Mangrove Sedang & $1000-1500$ & $0,20-0,30$ \\
Mangrove Padat & $>1500$ & $>0,30$ \\
\hline
\end{tabular}

Sumber: Susilo (2000) dalam Waas dan Nababan (2010); dimodifikasi

\section{HASIL DAN PEMBAHASAN Jenis Mangrove}

Berdasarkan hasil pengamatan lapangan, jenis mangrove di kawasan Taman Wisata Alam Teluk Youtefa antara lain dari genus Sonneratia, Rhizophora, Avicennia, Xylocarpus dan Bruguiera. Jenis mangrove dari genus Sonneratia terdiri atas jenis Sonneratia ovata dan S. alba. Genus Rhizophora antara lain jenis Rhizophora mucronata, $R$. apiculata dan $R$. stylosa. Genus Avicennia adalah jenis Avicennia alba, sedangkan dari genus Xylocarpus adalah jenis Xylocarpus granatum dan genus Bruguiera adalah jenis Bruguiera gymnorrhiza dan B. cylindrica.

Hasil pengamatan yang dilakukan tersebut tidak berbeda jauh dengan hasil beberapa penelitian yang telah dilakukan sebelumnya. Misalnya, hasil penelitian Handono dkk (2014) menemukan 10 jenis mangrove yang ada di kawasan Teluk Youtefa antara lain $R$. mucronata, R. apiculata, R. stylosa, S. ovate, S. alba, S. caseolaris, A. alba, B. gymnorrhiza, X. granatum dan Ceriops tagal. Selain itu, terdapat pula jenis mangrove B. gymnoriza, B. cylindrical, A. marina, Aegiceras comiculatum, Scyphyphora hydrphylacea, X. mollucensis dan Nypa fruticans, dimana jenis R. stylosa merupakan jenis yang paling umum dijumpai (Dinas Kelautan dan Perikanan Provinsi Papua, 2007; Arizona dkk, 2009).

\section{Sebaran dan Kerapatan Mangrove}

Berdasarkan hasil pengolahan citra satelit, maka dapat dikatakan bahwa vegetasi mangrove yang terdapat di kawasan Teluk Youtefa dari tahun 1994 hingga tahun 2017 telah mengalami pengurangan atau degradasi, baik dari aspek luasan mangrove maupun tingkat kerapatan mangrove. Hal ini didukung data Balai Pemantapan Kawasan Hutan (BPKH) Wilayah X Papua diacu dalam Handono dkk (2014) yang menjelaskan bahwa telah terjadi perubahan luasan tutupan hutan mangrove pada kawasan Teluk Youtefa mulai tahun 1967 sampai tahun 2008, dimana perubahan luasan tersebut masih berlangsung sampai saat ini mengingat tingginya aktifitas pembangunan di wilayah pesisir Kota Jayapura.

Hasil analisis citra pada Gambar 1, mangrove di kawasan Teluk Youtefa pada tahun 1994 diperoleh seluas 392,45 Ha, sedangkan luasan mangrove di kawasan Teluk Youtefa pada tahun 2017 ditemukan hanya seluas 233,12 Ha. Sebaran mangrove di kawasan Teluk Youtefa, baik pada tahun 1994 maupun tahun 2017 banyak ditemukan di sekitar pesisir Tobati, Enggros dan Nafri, serta sedikit ditemukan di sekitar Entrop dan Abepura Pantai. Pada tahun 1994, sebaran mangrove secara vertikal dari arah darat ke arah laut maksimal sejauh 1.171,54 meter di sekitar Tobati dan tergantung pada topografi masing-masing lokasi. Selain itu, terdapat pula mangrove secara berkelompok dengan luasan yang kecil dan secara vertikal ke arah laut maksimal sekitar 258,07 meter di sekitar pesisir Entrop dan Abepura Pantai. Sedangkan pada tahun 2017, dimana secara vertikal maksimal sejauh 1.081,66 meter di sekitar Tobati. Sama halnya dengan sebaran mangrove tahun 1994, terdapat pula mangrove secara berkelompok dengan luasan yang lebih kecil dan dimana secara vertikal ke arah laut maksimal sekitar 189,74 meter di sekitar pesisir Entrop.

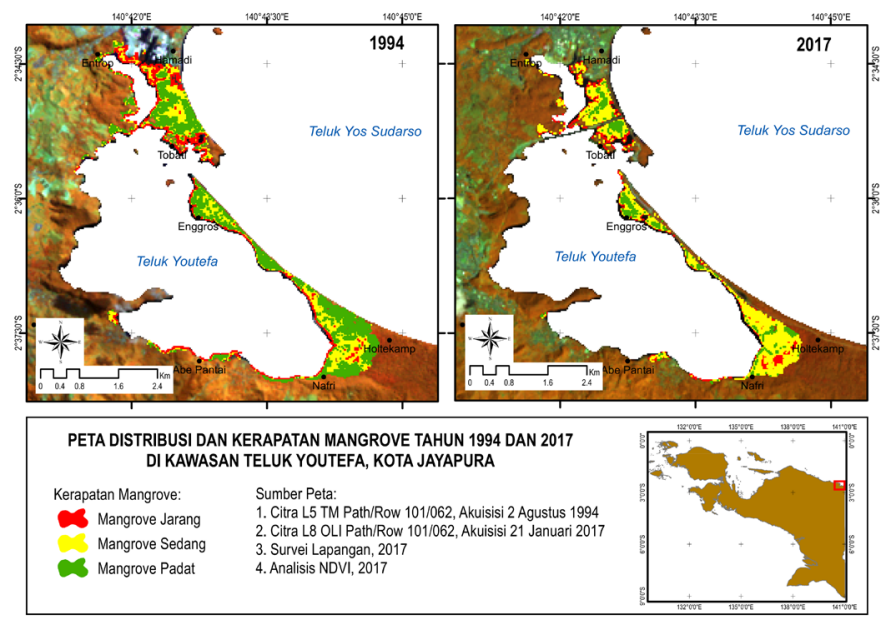

Gambar 1. Peta sebaran dan kerapatan mangrove kawasan Teluk Youtefa tahun 1994 dan 2017 
Kerapatan mangrove di kawasan Teluk Youtefa di setiap wilayah tumbuhnya mangrove berbeda-beda, tergantung pada banyaknya jumlah mangrove di daerah tersebut dan seberapa luas daerah tersebut. Semakin banyak jumlah mangrove di suatu daerah, maka semakin padat pula tingkat kerapatan mangrovenya. Luasan mangrove berdasarkan tingkat kerapatannya pada tiap lokasi tumbuhnya mangrove disajikan pada Tabel 2. Tingkat kerapatan mangrove pada tahun 1994 sangat baik, dimana mangrove kerapatan padat ditemukan tersebar luas hampir di semua kawasan yang terdapat mangrove, kecuali di wilayah pesisir Entrop pada bagian dalam teluk. Mangrove kerapatan sedang ditemukan dominan pada bagian tengah kawasan tumbuh mangrove, seperti di wilayah Tobati, Enggros dan Nafri. Sedangkan mangrove kerapatan jarang dominan ditemukan di bagian terluar kawasan tumbuh mangrove pada sepanjang garis bagian dalam Teluk Youtefa. Sedangkan pada tahun 2017, mangrove kerapatan padat ditemukan dominan hanya di kawasan Tobati dan Enggros, sedangkan mangrove kerapatan sedang hampir menyebar di seluruh kawasan tumbuh mangrove. Adapun mangrove kerapatan jarang dominan ditemukan di bagian luar kawasan tumbuhnya mangrove di Tobati, serta wilayah sebagian kecil di wilayah pesisir Entrop dan Abepura Pantai, kecuali di kawasan Nafri ditemukan di bagian tengah kawasan tumbuhnya mangrove.

Menurut Indriyanto (2006) diacu dalam Handono dkk (2014) bahwa tingkat kerapatan vegetasi mangrove dapat menentukan tingkat kerusakan hutan mangrove. Kriteria baku kerusakan mangrove adalah ukuran batas perubahan fisik dan hayati mangrove yang dapat ditenggang dan dapat menentukan kondisi atau status kondisi mangrove. Berdasarkan kriteria baku kerusakan mangrove dalam Keputusan Menteri Lingkungan Hidup No. 201 tahun 2004, maka dapat disimpulkan bahwa kondisi mangrove di kawasan Teluk Youtefa pada tahun 1994 dan 2017 masih berada dalam kondisi baik.

\section{Perubahan Luasan Mangrove}

Perubahan tutupan mangrove adalah bertambah atau berkurangnya luasan mangrove pada suatu periode. Perubahan tutupan mangrove terjadi apabila terjadi peningkatan luasan mangrove akibat adanya pertumbuhan hutan mangrove atau persebaran biji mangrove yang kemudian tumbuh di daerah yang asalnya tidak terdapat mangrove, ataupun pengurangan luasan mangrove terjadi apabila suatu daerah terdapat mangrove kemudian mangrove tersebut mati atau hilang digantikan dengan tutupan lahan lainnya.

Hasil tumpang tindih antara hasil klasifikasi tahun 1994 dengan tahun 2017 dapat memperlihatkan perubahan-perubahan yang terjadi pada kawasan mangrove. Kondisi mangrove di kawasan Teluk Youtefa saat ini telah mengalami degradasi bila dibandingkan dengan kondisi mangrove pada tahun 1994. Tingkat perubahan luasan mangrove di wilayah Taman Wisata Alam Teluk Youtefa, khususnya wilayah Entrop masuk dalam kategori rusak sedang (Antoh, 2015). Gambar 2 menjelaskan lokasi terjadinya perubahan tutupan mangrove, baik perubahan yang berdampak pada pengurangan maupun penambahan luas mangrove. Pengurangan luas mangrove dalam kurun waktu \pm 23 tahun sebesar 40,60\% dari luas mangrove tahun 1994. Dalam periode tersebut, terjadi pengurangan area mangrove seluas $167,91 \mathrm{Ha}$, akan tetapi pada beberapa lokasi tertentu telah terjadi penambahan area mangrove (tumbuhnya vegetasi mangrove) seluas 8,57 Ha.

Berdasarkan hasil interpretasi citra Landsat 5 TM tahun 1994 dan Landsat 8 OLI tahun 2017, serta dilakukan validasi dengan cara pengamatan langsung di lapangan, pada Gambar 3 terlihat jelas bahwa kawasan mangrove tahun 1994 sebagian besar terkonversi menjadi kawasan pemukiman tempat tinggal penduduk, kawasan pertokoan dan bangunan lainnya di sekitar Entrop. Pembukaan areal mangrove di kawasan Teluk Youtefa semakin diperparah dengan pengembangan Kota Jayapura yang sejalan dengan memanfaatkan beberapa areal tertentu (termasuk kawasan mangrove) untuk transportasi jalan lingkar (ringroad). Selain itu, hasil interpretasi juga menunjukkan adanya perubahan kawasan mangrove menjadi kawasan tanpa vegetasi.

Tabel 2. Luas mangrove berdasarkan tingkat kerapatan tahun 1994 dan 2017

\begin{tabular}{llcccc}
\hline \multirow{2}{*}{ Tahun Lokasi } & \multicolumn{3}{c}{ Kerapatan Mangrove (Ha) } & \multirow{2}{*}{ Total Luas (Ha) } \\
\cline { 3 - 4 } & & Jarang & Sedang & Padat & 208,71 \\
\cline { 2 - 4 } \multirow{2}{*}{1994} & Enggros -Nafri & 16,65 & 78,55 & 113,51 & 125,54 \\
& Tobati & 29,16 & 47,78 & 48,60 & 58,20 \\
& Abepura Pantai -Entrop & 21,87 & 18,66 & 17,67 & 392,45 \\
& Total Luas (Ha) & 67,68 & 144,99 & 179,78 & 141,15 \\
& Enggros -Nafri & 17,82 & 100,27 & 23,06 & 74,52 \\
& Tobati & 17,64 & 42,75 & 14,13 & 17,45 \\
& Abepura Pantai -Entrop & 6,30 & 9,71 & 1,44 & 233,23 \\
\hline
\end{tabular}

Sumber: Hasil Analisis (2017) 


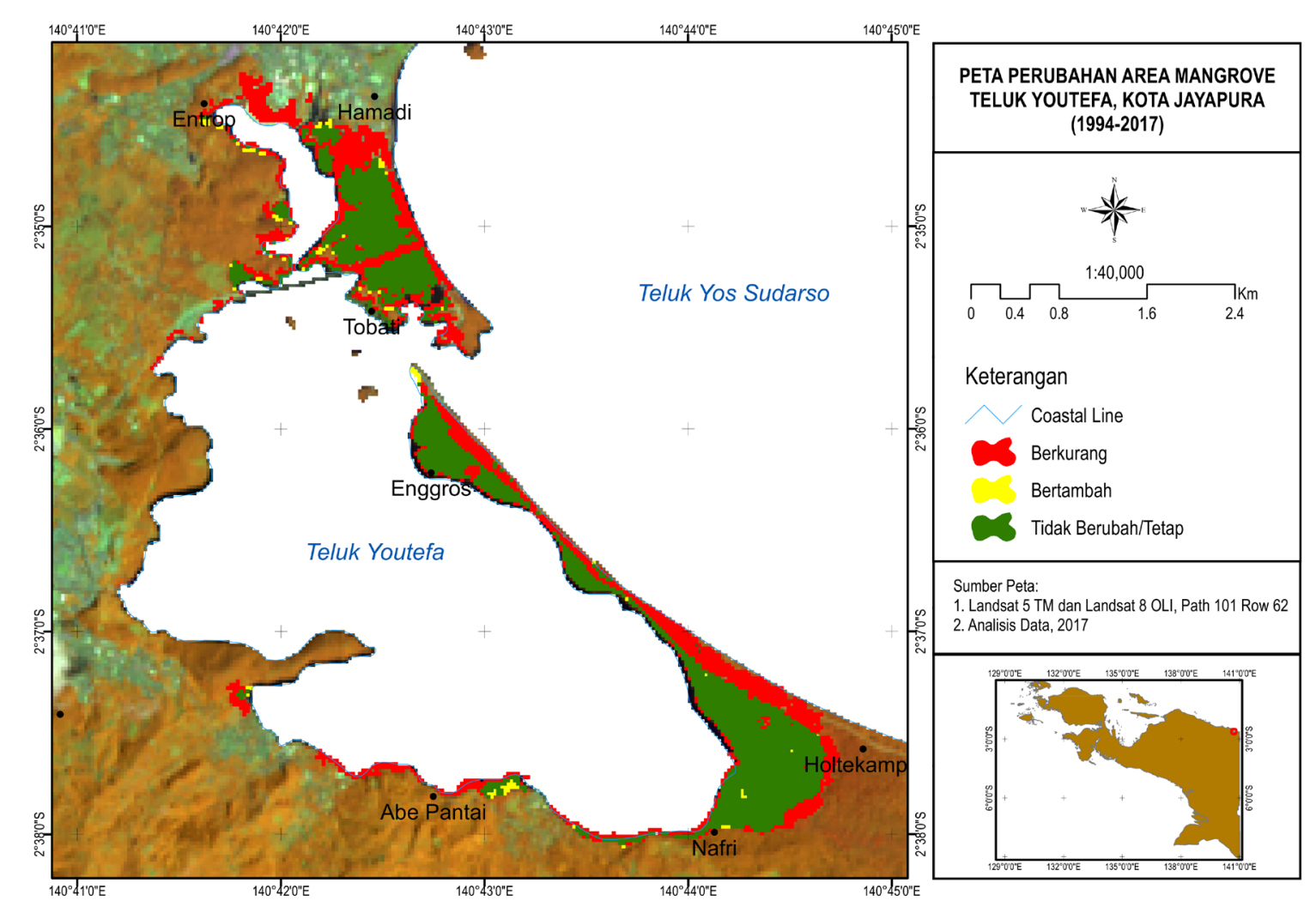

Gambar 2. Peta sebaran perubahan mangrove kawasan Teluk Youtefa tahun 1994-2017
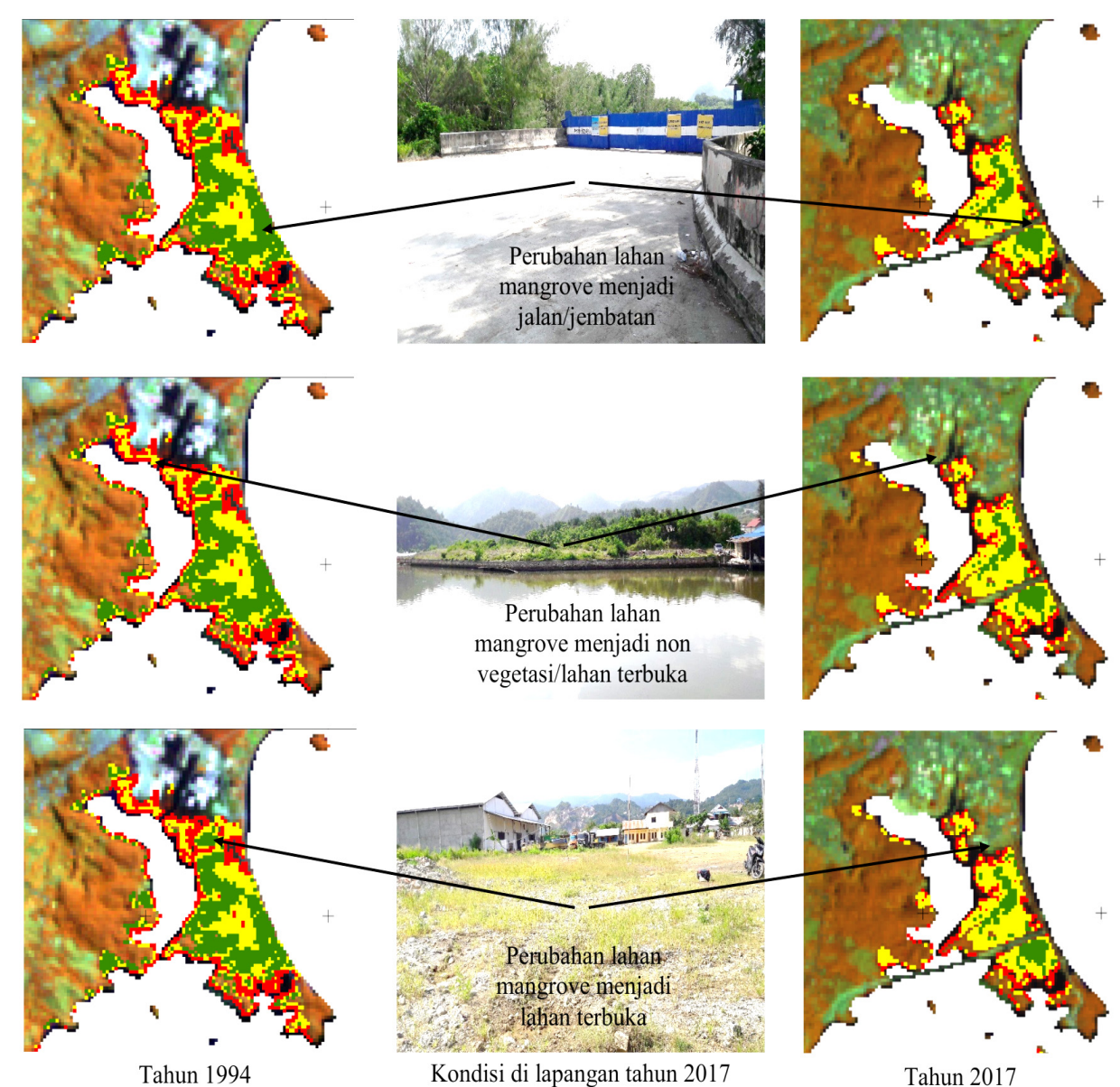

Gambar 3. Bentuk perubahan dan konversi lahan mangrove kawasan Teluk Youtefa tahun 1994 ke tahun 2017 
Perubahan fungsi kawasan mangrove Teluk Youtefa yang terjadi saat ini selain menyebabkan berkurangnya luasan dan kerapatan vegetasi mangrove, kemungkinan dapat menyebabkan hilangnya beberapa spesies mangrove apabila perubahan fungsi kawasan mangrove tersebut berlangsung secara terus-menerus. Sedangkan penambahan luas mangrove kemungkinan karena adanya beberapa program beberapa institusi terkait untuk melakukan penanaman ulang mangrove di dalam kawasan Teluk Youtefa, selain tumbuhnya vegetasi mangrove secara alami. Secara umum, penambahan luasan mangrove masih didominasi oleh mangrove kerapatan jarang. Perubahan lain yang terjadi adalah perubahan tingkat kerapatan mangrove pada lokasi yang sama. Perubahan tingkat kerapatan mangrove dapat mengindikasikan bahwa telah terjadi perubahan kualitas mangrove di kawasan Teluk Youtefa. Tabel 3 menyajian luas perubahan kerapatan mangrove, serta perubahan lain yang terjadi pada mangrove di kawasan Teluk Youtefa. Pada tersebut terlihat jelas bahwa pengurangan tutupan mangrove lebih tinggi dibandingkan dengan penambahan luas tutupan mangrove. Selain itu, perubahan mangrove kerapatan padat menjadi kerapatan sedang dan jarang, ataupun hilangnya tutupan mangrove kerapatan padat menjadi tutupan lahan lain dalam kurun waktu \pm 23 tahun lebih tinggi dan tidak diimbangi dengan penambahan luasan tutupan mangrove kerapatan padat.

Tabel 3. Bentuk perubahan mangrove kawasan Teluk Youtefa 1994-2017

\begin{tabular}{lc}
\hline Bentuk Perubahan Mangrove 1994-2017 & Luas (Ha) \\
\hline Tidak berubah (kerapatan jarang) & 11,97 \\
Tidak berubah (kerapatan sedang) & 67,41 \\
Tidak berubah (kerapatan padat) & 26,54 \\
Perubahan kerapatan jarang-sedang & 7,92 \\
Perubahan kerapatan jarang-padat & 0,63 \\
Perubahan kerapatan sedang-jarang & 17,19 \\
Perubahan kerapatan sedang-padat & 10,53 \\
Perubahan kerapatan padat-jarang & 10,08 \\
Perubahan kerapatan padat-sedang & 72,27 \\
Mangrove hilang (kerapatan jarang) & $-47,16$ \\
Mangrove hilang (kerapatan sedang) & $-49,86$ \\
Mangrove hilang (kerapatan padat) & $-70,89$ \\
Mangrove bertambah (kerapatan jarang) & 2,52 \\
Mangrove bertambah (kerapatan sedang) & 5,13 \\
Mangrove bertambah (kerapatan padat) & 0,92 \\
\hline Total Luas Mangrove yang Hilang & $-167,91$ \\
\hline Total Luas Mangrove yang Bertambah & 8,57 \\
\hline Total luas degradasi mangrove & $-159,34$ \\
\hline Sumber: Hasil Analisis (2017)
\end{tabular}

Kondisi mangrove di kawasan Teluk Youtefa secara ekstrim berkurang karena adanya peningkatan kegiatan pembukaan areal yang mengkonversi kawasan mangrove menjadi peruntukan lain. Menurut Arizona dkk (2009), komposisi vegetasi mangrove yang terdapat di Kampung Tobati yang lahan mangrovenya telah terkonversi lebih didominasi oleh genus Rhizophora (R. mucronata, R. apiculata dan R. stylosa). Selain itu, aktivitas masyarakat yang tidak peduli terhadap pemeliharaan dan perlindungan kawasan pesisir dengan dikonversinya kawasan manggrove secara berlebihan, penangkapan ikan yang tidak ramah lingkungan, lemahnya penataan, kurangnya koordinasi antara pemerintah dan kelembagaan masyarakat, serta lemahnya penegakan hukum di wilayah pesisir dan laut (Mano, 2011). Dampak dari mengkonversi dan penebangan mangrove tidak hanya berakibat terhadap hilangnya tutupan mangrove tapi yang lebih penting adalah berubahnya struktur komunitas mangrove (Ferreira et al., 2009). Beberapa hasil kajian menyatakan bahwa gangguan secara antropogenik maupun alami dapat berpengaruh terhadap kerapatan tegakan, basal area dan kompleksitas jika dibandingkan dengan mangrove yang tidak mengalami gangguan (Bandeira et al., 2009; Urrego et al., 2014).

Apabila mengacu pada data BPKH Wilayah X Papua diacu dalam Handono dkk (2014), dimana kondisi lahan mangrove pada kawasan Teluk Youtefa mulai tahun 1967 sampai tahun 2008 telah mengalami perubahan luasan tutupan lahan mangrove dengan laju degradasi sekitar 1,33-6,81 Ha/tahun (Tabel 4). Apabila data tersebut dikombinasikan dengan hasil analisis yang telah dilakukan, maka kondisi mangrove di kawasan Teluk Youtefa selalu terjadi degradasi atau pengurangan luasan area mangrove dari tahun ke tahun. Dari tahun 1967 hingga tahun 2017 telah terjadi pengurangan luasan area mangrove sebesar 278,12 Ha. Pada beberapa tahun belakangan, tingkat kerusakan mangrove di kawasan Teluk Youtefa dapat ditekan dengan semakin tingginya tingkat kepedulian dari berbagai pihak yang berkepentingan seperti Pemerintah Daerah, lembaga pengelola kawasan Teluk Youtefa, akademisi dan masyarakat dalam menjaga kelestarian ekosistem mangrove di kawasan Teluk Youtefa. Selain itu adanya kesadaran untuk melakukan kegiatan penanaman ulang mangrove di beberapa lokasi di kawasan Teluk Youtefa. Oleh karena itu, diperlukan dukungan serius seluruh pemangku kepentingan dalam pengelolaan mangrove di kawasan Taman Wisata Alam Teluk Youtefa untuk mempertahankan eksistensi dan keberlangsungannya. Selain itu, untuk menekan kegiatan konversi mangrove secara illegal perlu adanya ketegasan dan penegakan aturan-aturan yang berlaku mengingat kawasan Teluk Youtefa merupakan kawasan Taman Wisata Alam sebagai upaya preventif dalam mencegah timbulnya permasalahan dan dalam upaya menjaga kelestarian kawasan Taman Wisata Alam Teluk Youtefa. 
Baigo Hamuna dan Rosye H.R. Tanjung/Majalah Geografi Indonesia Vol. 32, No.2, September 2018 : 115 - 122

Tabel 4. Perubahan luasan mangrove di kawasan Teluk Youtefa periode 1967-2017

\begin{tabular}{|c|c|c|c|}
\hline \multirow{2}{*}{ Tahun } & \multicolumn{3}{|c|}{ Luas Mangrove (Ha) } \\
\hline & Primer & Sekunder & Total Luas \\
\hline $1967^{1}$ & 364,95 & 146,29 & 511,24 \\
\hline $1994^{2}$ & - & - & 392,45 \\
\hline $2000^{1}$ & 134,67 & 146,26 & 280,93 \\
\hline $2004^{1}$ & 112,81 & 146,29 & 259,10 \\
\hline $2008^{1}$ & 96,13 & 146,29 & 242,42 \\
\hline $2017^{2}$ & - & - & 233,12 \\
\hline
\end{tabular}

Sumber: ${ }^{1}$ BPKH Wilayah X Papua dalam Handono dkk (2014) ${ }^{2}$ Hasil Analisis (2017)

\section{KESIMPULAN}

Mangrove kawasan Teluk Toutefa telah mengalami perubahan luasan maupun kerapatan mangrove. Total perubahan luas mangrove seluas $159,34 \mathrm{Ha}$, dimana luas mangrove pada tahun 1994 seluas 397,45 Ha sedangkan tahun 2017 hanya seluas 233,12 Ha. Pada beberapa lokasi terjadi kehilangan mangrove seluas 167,91 Ha dan terjadi penambahan luas tutupan mangrove seluas 8,57 Ha. Perubahan kerapatan mangrove dari kerapatan padat menjadi kerapatan sedang dan jarang seluas $82,35 \mathrm{Ha}$, kerapatan sedang menjadi padat dan jarang seluas 27,72 Ha, serta kerapatan jarang menjadi sedang dan padat hanya seluas $8,55 \mathrm{Ha}$. Secara umum, Penambahan luas tutupan mangrove disebabkan oleh adanya program rehabilitasi atau penanaman mangrove yang masih didominasi oleh mangrove kerapan jarang, sedangkan pengurangan luas tutupan mangrove disebabkan oleh alih fungsi mangrove menjadi penutup lahan lainnya seperti pemukiman, jalan atau jembatan, penebangan mangrove dan perubahan secara alami.

\section{DAFTAR PUSTAKA}

Antoh, A. (2015). Peranan Hutan Mangrove Pada Ekosistem Pesisir yang Terabaikan (Kerusakan Hutan Mangrove di Taman Wisata Alam Teluk Youtefa, Kota Jayapura, Prov. Papua). Warta Konservasi Lahan Basah, 23(1), 12-13.

Arizona, M., Sunarto, \& Tandjung, D. (2009). Kerusakan Ekosistem Mangrove Akibat Konversi Lahan Di Kampung Tobati dan Kampung Nafri, Jayapura. Majalah Geografi Indonesia, 23(3), 18-39.

Bandeira, S.O., Macamo, C.C.F., Kairo, J.G., Amade, F., Jiddawi, N. \& Paula, J. (2009). Evaluation of mangrove structure and condition in two transboundary areas in the western Indian ocean. Aquatic Conservation: Mar. Freshw. Ecosyst., 19 (SPEC.ISS.), S46-S55.

Bengen, D.G. (2000). Pengenalan dan Pengelolaan Ekosistem Mangrove. Bogor: Pusat Kajian Sumberdaya Pesisir dan Lautan-Institut Pertanian Bogor.
Bosire, J.O., Dahdouh-Guebas, F., Jayatissa, L.P., Koedam, N., Lo Seen, D. \& Nitto, D. (2005). How Effective Were Mangroves As A Defense Against the Recent Tsunami? Current Biology, 15, 443-447.

Dinas Kelautan dan Perikanan (DKP) Provinsi Papua. (2007). Rencana Strategis Pengelolaan Mangrove Kota Jayapura. Jayapura: Dinas Perikanan dan Kelautan Provinsi Papua.

Faizal, A. \& Amran, M.A. (2005). Model Transformasi Indeks Vegetasi yang Efektif Untuk Prediksi Kerapatan Mangrove Rhizophora mucronata. Prosiding PIT MAPIN XIV ITS, Surabaya, 14-15 September 2005.

Faturrohmah, S. \& Marjuki, B. (2017). Identifikasi Dinamika Spasial Sumberdaya Mangrove di Wilayah Pesisir Kabupaten Demak Jawa Tengah. Majalah Geografi Indonesia, 31(1), 56-64.

Ferreira, M.A., Andrade, F., Bandeira, S.O., Cardoso, P., Mendes, R.N. \& Paula, J. (2009). Analysis of cover change(1995-2005) ofTanzania/Mozambiquetransboundary mangroves usinglandsatimagery. Aquatic Conservation: Mar. Freshw. Ecosys., 19(S1), S38S45.

Giri, C.P., Ochieng, E., Tieszen, L.L., Zhu, Z., Singh, A., Loveland, T. \& Duke, N. (2011). Status and distribution of mangrove forests of the world using earth observation satellite data. Glob. Ecol. Biogeogr., 20(1), 154-159.

Green, E.P., Mumbay, P.J., Edwards, A.J. \& Clark, C.D. (2000). Remote Sensing Hand Book for Tropical Coastal Management. UNESCO Publishing.

Hamuna, B., Sari, A.N. \& Alianto. (2018). Kajian Kerentanan Wilayah Pesisir Ditinjau Dari Geomorfologi dan Elevasi Pesisir Kota dan Kabupaten Jayapura, Provinsi Papua. Jurnal Wilayah dan Lingkungan, 6(1), 1-14.

Handono, N., Tanjung, R.H.R. \& Zebua, L.I. (2014). Struktur Vegetasi dan Nilai Ekonomi Hutan Mangrove Teluk Youtefa, Kota Jayapura, Papua. Jurnal Biologi Papua, 6(1), 1-11.

Hidayah, Z. \& Wiyanto, D.B. (2013). Analisa Temporal Perubahan Luas Hutan Mangrove di Kabupaten Sidoarjo dengan Memanfaatkan Data Citra Satelit. Jurnal Bumi Lestari, 13(2), 318-326.

Imburi, C.S., Danoedoro, P. \& Murti, S.H. (2015). Pemetaan Hutan Mangrove Di Estuari Sungai Andai, Manokwari Papua Barat Berdasarkan Metode Density Slicing Berbasis Citra Alos AVNIR-2. Majalah Geografi Indonesia, 29(1), 1930.

Jaya, I.N.S. (2002). Separabilitas Spektral Beberapa Jenis Pohon Menggunakan Citra Compact Airborne Spectrograph Imager (CASI): Studi Kasus di Kebun Raya Bogor. Jurnal Manajemen Hutan Tropika, 3 (2), 57-73.

Jhonnerie, R., Siregar, V.P., Nababan, B., Prasetyo, L.B. \& Wouthuyzen, S. (2014). Deteksi Perubahan Tutupan Mangrove Menggunakan Citra Landsat 
Berdasarkan Klasifikasi Hibrida di Sungai Kembung, Pulau Bengkalis, Provinsi Riau. Jurnal Ilmu dan Teknologi Kelautan Tropis, 6(2), 491-506.

Keputusan Menteri Lingkungan Hidup No. 201 Tahun 2004, tentang Kriteria Baku Kerusakan Mangrove.

Mano, I. (2011). Wilayah Pesisir Jayapura Miliki SDA yang Potensial. (Online) http://dkp.papua.go.id/ berita-129-9-wilayah-pesisir--jayapura-milikisda-yang-potensial.html [diakses 15 September 2017]

Paulangan, Y.P. (2014). Potensi Ekosistem Mangrove di Taman Wisata Teluk Youtefa Kota Jayapura Papua. Jurnal Kelautan, 6(1), 88-98.

Purwanto, A.D., Asriningrum, W., Winarso, G. \& Parwati, E. (2014). Analisis Sebaran dan Kerapatan Mangrove Menggunakan Citra Landsat 8 di Segara Anakan, Cilacap. Prosiding Seminar Nasional Penginderaan Jauh 2014, 232-241. Bogor, April 2014.

Rumada, I.W., Kesumadewi, A.A.I. \& Suyarto, R. (2015). Interpretasi Citra Landsat 8 Untuk Identifikasi Kerusakan Hutan Mangrove Di Taman Hutan Raya Ngurah Rai Bali. E-Jurnal Agroekoteknologi Tropika, 4(3), 234-243.

Suwargana, N. (2010). Analisis Perubahan Hutan Mangrove Menggunakan Data Penginderaan Jauh di Pantai Bahagia, Muara Gembong, Bekasi. Jurnal Penginderaan Jauh, 5, 64-74.

Urrego, L.E., Molina, E.C. \& Suárez, J.A. (2014). Environmental and anthropogenic influences on the distribution, structure, and floristic composition of mangrove forests of the gulf of urabá (Colombian Caribbean). Aquat. Bot., 114, 42-49.

Valiela, I., Bowen, J.L. \& York. J.K. (2001). Mangrove Forests: One of the World's Threatened Major Tropical Environments. BioScience, 51(10), 807815.

Waas, H.J.D. \& Nababan, B. (2010). Pemetaan dan Analisis Index Vegetasi Mangrove di Pulau Saparua, Maluku Tengah. Jurnal Ilmu dan Teknologi Kelautan Tropis, 2(1), 50-58.

Wulandari, D. \& Samsu, F. (2013). Identifikasi Sebaran dan Tingkat Kesuburan Mangrove Melalui Pemantauan Indeks Vegetasi Dari Satelit Landsat 7.0 ETM+ Menggunakan Fuzzy Logic (Studi Kasus Pantai Pesisir Timur Surabaya/Pamurbaya). Jurnal Neutrino, 6(1), 60-67. 